\title{
Rancangan Model Kebijakan Penanggulangan Kemiskinan Dalam Perspektif Pemberdayaan Perempuan (Kajian Terhadap Implementasi Program Keluarga Harapan di Kecamatan Sumberbaru Kabupaten Jember)
}

\author{
Liawati Suntiana $^{1}$, Sanggar Kanto ${ }^{2}$, Soenyono ${ }^{3}$ \\ ${ }^{1}$ Magister Sosiologi, Fakultas IImu Sosial dan Politik, Universitas Brawijaya
}

\begin{abstract}
Abstrak
Penelitian ini bertujuan untuk menganalisis (1) partisipasi perempuan dalam implementasi kebijakan PKH di Kecamatan Sumberbaru Kabupaten Jember; (2) faktor-faktor yang menjadi pendukung dan penghambat dalam proses pemberdayaan perempuan dalam pelaksanaan PKH di Kecamatan Sumberbaru Kabupaten Jember; (3) rancangan model penanggulangan kemiskinan dalam perspektif pemberdayaan perempuan. Penelitian ini menggunakan teori kebijakan sosial dan pemberdayaan perempuan dengan pendekatan longwe sebagai alat analisanya, sedangkan jenis penelitian adalah deskriptif kualitatif. Lokasi penelitian di Kecamatan Sumberbaru Kabupaten Jember. Informan dari penelitian ini adalah tenaga pendamping, perempuan penerima PKH dan para stakeholders yang dipilih dengan menggunakan tekhnik purposive sampling, dimana data yang terkumpul dianalisis mengguakan model interaktif Miles dan Huberman. Hasil dari penelitian ini adalah (1) partisipasi perempuan di dalam implementasi PKH belum optimal; (2) Faktor pendukung bahwa uang bantuan PKH bisa digunakan untuk memenuhi kebutuhan pokok setelah kewajiaban intervensi pendidikan atau kesehatan terpenuhi sehingga mampu meningkatkan ekonomi daya beli masyarakat sedangkan faktor penghambat program kebijakan PKH yang bersifat Top Down yang tidak melibatkanya peran perempuan RTSM dalam proses awal perencanaan sampai dengan evaluasi menyebakan lemahnya partisipasi perempuan; (3) rancangan model kebijakan penanggulangan kemiskinan dengan perspektif pemberdayaan perempuan yang diperoleh dari hasil implementasi PKH di Kecamatan Sumberbaru Kabupaten Jember adalah penyempurnaan dari PKH dengan merubah dari kebijakan Top Down menjadi kebijakan bottom up dan harus ada sinergitas dengan kebijakan penanggulangan kemiskinan yang lainya.
\end{abstract}

Kata kunci: Program Keluarga Harapan (PKH), Partisipasi dan Pemberdayaan Perempuan

Abstract

The aimed of the study is described (1) women's participation toward the implementation Program Keluarga Harapan (PKH) in Kecamatan Sumberbaru, Kabupaten Jember; (2) factors which could enable and inhander women empoweriment process toward the implementation of PKH Program in Kecamatan Sumberbaru, Kabupaten Jember; (3) the Program model of poverty prevention in the empowerment of women perspective toward the implementation of PKH program. This study social policy and women empowerment theories a tool of analysis, descriptive qualitative method was used with the purposive sampling to gather data from several informants including the facilitators of PKH and women who receive this program in Kecamatan Sumberbaru Kabupaten Jember include. The data analyzed using interactive data of Miles and Huberman. The result of the study shows that (1) women's participation in Kecamatan Sumberbaru Kabupaten Jember is not optimal; (2) Enabling factors toward the implementation of PKH can improve economic earning is a program that should be maintained and improved. However, top-down process has hampered the women to be more participate in PKH program from the planning and evaluating this program. The poverty prevention mode has been the change of a top down into a bottom-up policy. It also requires a synergy with other poverty alleviation policies.

Keywords: Program Keluarga Harapan (PKH), women participation and women empowerment

Corresponding Adress:

Liawati Suntiana

Email : liasuntiana@gmail.com

Alamat : Program Magister Sosiologi Kajian Kemiskinan

Fakultas Ilmu Sosial dan Politik 


\section{PENDAHULUAN}

Program-program penanggulangan kemiskinan yang sudah berjalan secara konseptual sudah memenuhi standar dari tujuan utama untuk menurunkan tingkat kemiskinan di Indonesia, hanya saja permasalahan utama yang terjadi adalah pada implementasi program penanggulangan kemiskinan yang kurang signifikan. Dari perspektif orang miskin (Kempson 1996: 18) ${ }^{1}$ menunjukkan bahwa kemiskinan berdampak pada empat bidang yang luas, yakni (1) psikologis, di mana kemiskinan berkaitan dengan hilangnya harga diri, perasaan tak berdaya, kemarahan, kecemasan dan perasaan bosan yang sangat kuat; (2) fisik, yakni kemiskinan dianggap merusak kesehatan dan well-being; (3) relasional, yakni kemiskinan membuat hubungan sosial dan personal buruk dan stigma yang dikaitkan dengan kemiskinan sangat mewarnai relasi tersebut; serta (4) praktis, dimana kemiskinan membatasi pilihan, belanja dan pengasuhan anak. Artinya kemiskinan nyaris merusak semua bidang kehidupan, terutama bila kemiskinan tersebut tergolong kronis. Pakpahan (2009: 3$)^{2}$ menyatakan bahwa risiko anak yang berasal dari keluarga miskin kronis tetap hidup dalam kemiskinan pada saat dewasa adalah 35\% lebih tinggi dibandingkan anak yang bukan dari keluarga miskin kronis.

Salah satu kebijakan sosial penanggulangan kemiskinan adalah Program Keluarga Harapan atau yang selanjutnya disebut PKH merupakan salah satu program pemerintah pusat yang menggunakan paradigma pembangunan kemanusiaan yang memposisikan manusia sebagai subjek pembangunan menggunakan strategi pemberdayaan yaitu pemberdayaan perempuan, balita dan anak usia sekolah serta partisipasi mereka dalam program kebijakan tersebut.

Desain PKH ini bertujuan meningkatkan investasi dibidang sumber daya manusia untuk generasi yang akan datang. Dimana dalam program ini menempatkan perempuan pada posisi yang unik sebagai penerima bantuan. Para perempuan penerima bantuan harus mampu mengatur dan mengelola uang bantuan yang diterima sesuai dengan tuntutan yang diberikan oleh pendamping program dimana uang tersebut harus digunakan untuk memenuhi kebutuhan kesehatan dan pendidikan anak-anaknya. Dalam implementasi PKH para peserta atau penerima bantuan yaitu perempuan diupayakan harus memenuhi kewajiban yang dipersyaratkan dalam ketetapan yang ada dalam PKH. Bentuk pelaksanaan kewajiban dalam PKH bisa disebut dengan partisipasi perempuan penerima bantuan dimana harus aktif dalam setiap alur pelaksanaan PKH.

Pelaksanaan PKH di Jawa Timur sendiri sampai dengan tahun 2014 sudah terlaksana diseluruh Kabupaten atau Kota di Jawa Timur. Sedangkan penerima Program Keluarga Harapan di Jember merupakan yang terbesar di Jawa timur. Peneleiti tertarik meneliti pelaksanaan implementasi kebijakan PKH di Kabupaten Jember tepatnya di Kecamatan Sumberbaru dimana jumlah penduduk perempuan lebih banyak dibandingkan laki-laki diharapkan Kabupaten Jember bisa memberi gambaran rancangan model baru tentang penanggulangan kemiskinan dalam perspektik pemberdayaan perempuan.

Dalam data Tim Nasional Percepatan Penanggulangan Kemisknan (TNP2K) tahun 2012 jumlah penduduk miskin di Jember adalah 417.000 jiwa (18,57\% dari penduduk Jember). Namun sampai saat ini tidak ada data yang pasti berapa jumlah perempuan miskin di Jember. Jumlah penduduk perempuan miskin di Jawa Tmur mencapai 3.735.300.000 jiwa, dan di Indonesia adalah 18.076.900.000 jiwa, (Data BPS tahun 2013) ${ }^{3}$, sedangkan di Kabupaten Jember menurut data Tim Nasional Percepatan Penanggulangan Kemiskinan (TNP2K) tahun 2011 status kesejahteraan perempuan desil 1, desil 2 dan desil 3 (status kesejahteraan dibawah 30\%) usia dibawah 45 tahun sebanyak 4.347 jiwa, usia 45 tahun sampai dengan 60 tahun sebanyak 11.642 jiwa, usia diatas 60 tahun sebanyak 23.028 jiwa (Data BPS tahun 2014) 4

Dari pelaksanaan PKH di Kecamatan Sumberbaru Kabupaten Jember diharapkan memiliki implementasi positif kepada rumah tangga sangat miskin (RTSM) sebagai rumah tangga sasaran (RTS) sehingga nanti akan memunculkan suatu rancangan model baru dalam penanggulangan kemiskinan dalam perspektif pemberdayaan perempuan, tetapi pada kenyataanya tingkat kesejahteraan di Kabupaten Jember masih tinggi meskipun sudah ada PKH sebagai salah satu kebijakan penanggulangan kemiskinan yang berperspektif pemberdayaan perempuan selain itu posisi perempuan di Kecamatan Sumberbaru masih dipandang sebelah mata yang tidak memiliki kemampuan untuk mengerjakan hal hal yang bersifat kepemimpinan. Sehingga muncul istilah perempuan sebagai "Konco wingking" yang berarti hanya mengurusi hal hal yang bersifat 
rumah tangga, baik itu yang berhubungan dengn anak maupun yang berhubungan dengan aktifitas rumah tangga yang lain.

Dalam Arif, Sirojuddin dkk $(2013)^{5}$ melakukan penelitian (Wrorking Paper) dengan judul "Is Conditionality Pro Women? (A Case Study Conditional Cash Transfer In Indonesia)". Penelitian tersebut meneliti program CCT atau dikenal dengan Program Keluarga Harapan Di Indonesia untuk mengetahui dampak CCT atau PKH terhadap perempuan sebagai pengatur dalam rumah tangga di Provinsi Jawa Barat dan Provinsi Nusa Tenggara Timur. Hasil penelitian ini menunjukkan bahwa sejauh ini belum ada perubahan signifikan dalam tugas-tugas rumah tangga perempuan sehubungan dengan pelaksanaan program PKH. Terlepas dari kenyataan bahwa pertemuan ini terkait erat dengan tugas-tugas sehari-hari normal perempuan, seperti merawat anak-anak atau membawa mereka ke posyandu, hal ini dapat dikaitkan dengan fakta bahwa belum ada mekanisme pengawasan formal untuk mengevaluasi pemenuhan persyaratan Program yang membentuk prinsip-prinsip dasar dari program PKH. Temuan penelitian ini juga menunjukkan bahwa sementara program PKH secara khusus dimaksudkan untuk meningkatkan kualitas sumber daya manusia di kalangan rumah tangga sangat miskin, khususnya pendidikan dan kesehatan anak-anak, manfaat PKH yang benarbenar digunakan untuk memenuhi kebutuhan rumah tangga. Semua responden di empat desa penelitian mengatakan bahwa uang PKH mereka hanya bermanfaat dalam memenuhi berbagai kebutuhan rumah tangga, khususnya dalam membeli makanan dan kebutuhan lainnya setiap hari dan sebagai pembayaran atas utang atau tagihan listrik. Dari penelitian terdahulu tersebut, peneliti tertarik untuk meneliti tentang implementasi PKH untuk menghasilkan sebuah rancangan model penanggulangan kemiskinan dalam perspektif pemberdayaan perempuan.

Rumusan masalah dalam penelitian ini adalah: (1) Bagaimana partisipasi perempuan dalam implementasi kebijakan PKH di Kecamatan Sumberbaru Kabupaten Jember? (2) Faktorfaktor apa saja yang menjadi pendukung dan penghambat dalam proses pemberdayaan perempuan melalui pelaksanaan PKH di Kecamatan Sumberbaru Kabupaten Jember? (3) Bagaimana rancangan model penanggulangan kemiskinan dalam perspektif pemberdayaan perempuan yang dihasilkan dari implementasi kebijakan $\mathrm{PKH}$ ?
Adapun tujuan dari penelitian ini adalah sebagai berikut:

1) Mengetahui, menganalisis dan menginterpretasi partisipasi perempuan dalam implementasi kebijakan PKH di Kecamatan Sumberbaru Kabupaten Jember;

2) Menemukan menganalisis dan menginterpretasi faktor-faktor yang menjadi pendukung dan penghambat dalam proses pemberdayaan perempuan melalui pelaksanaan PKH di Kecamatan Sumberbaru Kabupaten Jember;

3) Menemukan rancangan model penanggulangan kemiskinan dalam perspektif pemberdayaan perempuan yang dihasilkan dari implementasi kebijakan PKH.

\section{METODE PENELITIAN}

Metode dalam penelitian ini menggunakan jenis penelitian kualitatif dengan pendekatan deskriptif kualitatif untuk memberi gambaran tentang implementasi kebijakan sosial penanggulangan kemiskinan PKH di kecamatan Sumberbaru Kabupaten Jember sehingga bisa dibuat rancangan model baru kebijakan penanggulangan kemiskin yang berperspektif pemberdayaan perempuan.

\section{Metode Pengumpulan Data}

Tekhnik pengumpulan datanya yang pertama adalah melakukan wawancara mendalam (depth interview) dengan para informan yang penenentuanya secara purposive (tenaga pendamping $\mathrm{PKH}$, perempuan penerima $\mathrm{PKH}$ dan stakeholders PKH. Selanjutnya melakukan observasi atau pengamatan untuk melengkapi, melakukan check, richeck dan crosscheck terhadap data yang diperoleh dari hasil wawancara dengan para informan dilokasi penelitian. Yang terakhir adalah pelaksanaan Focus Group Discussion (FGD) untuk menggali informasi dengan dari para informan. Dan yang terakhir adalah melakukan dokumentasi atau pengumpulan data yang sudah tersusun dalam bentuk dokumen-dokumen lain yang memperkuat data dalam penelitian ini.

\section{HASIL DAN PEMBAHASAN}

Kecamatan Sumberbaru adalah kecamatan paling barat di Kabupaten Jember, Provinsi Jawa Timur, Indonesia. Secara parsial dan sektoral, kaum perempuan di Kecamatan Sumberbaru Kabupaten Jember mengalami ketertinggalan dan kesenjangan. Perempuan berada dalam posisi bargaining power yang lemah dibanding 
dengan laki-laki di berbagai aspek. Sistem budaya masyarakat patriarki menjadi akar permasalahan dari kesenjangan dan ketertinggalan perempuan. Bias gender ini hampir terjadi di semua bidang kehidupan. Hal ini salah satunya karena dipengaruhi rendahnya tingkat pendidikan di masyarakat. Didukung pula dari hasil survey lapang dari 9 responden perempuan hanya 2 orang yang lulus SD dan sisanya tidak pernah lulus SD. Tingkat pengetahuan yang rendah ini mendorong terjadinya kesenjangan sosial yang dialami perempuan.

\section{1) Kebijakan Sosial Penanggulangan Kemiskinan Program Keluarga Harapan (PKH)}

a) Intervensi kesehatan

Berkaitan dengan kesehatan, RTSM yang sudah ditetapkan menjadi peserta PKH dan memiliki kartu PKH, diwajibkan memenuhi persyaratan kesehatan yang sudah ditetapkan dalam protokol pelayanan kesehatan. Adapun peserta PKH yang dikenakan persyaratan kesehatan adalah RTSM yang memiliki lbu hamil atau nifas, anak balita atau anak usia 5-7 tahun yang belum masuk pendidikan SD. Perempuan hamil, melahirkan atau nifas, perempuan yang memiliki bayi dan balita (anak usia sampai dengan 7 tahun tapi belum masuk SD) penerima PKH wajib datang ke pos pelayanan kesehatan yaitu pos pelayanan terpadu yang ada disetiap desa di Kecamatan Sumberbaru Kabupaten Jember yang sudah disediakan pemerintah Kabupaten Jember.

Dari hasil penelitian ditemukan bahwa perempuan penerima bantuan dengan komponen kesehatan uang bantuan tidak digunakan untuk mengakses kesehatan karena fasilitas pelayanan kesehatan diberikan secara gratis, sehingga uang bantuan bisa digunakan untuk kebutuhan lain seperti peningkatan pelayanan gizi dari makanan yang dikonsumsi ataupun minumanya. Terbukti dari para informan tersebut menyebutkan bahwa uang bantuanya dipakai untuk kebutuhan konsumsi membeli susu ataupun untuk kebutuhan lauk pauk. Sehingga dari kegiatan perekonomian keluarga RTSM penerima PKH ada peningkatan daya beli dari sektor konsumsi.

Dari hasil wawancara dengan para informan, intervesi kesehatan untuk RTSM perlu diperluas tidak hanya untuk ibu hamil, ibu melahirkan dan atau nifas, bayi serta balita tetapi juga untuk RTSM penerima PKH terutama perempuan yang tidak memiliki komponen kesehatan tersebut sehingga kesehatan mereka terjamin. Jalan lainnya adalah adanya dukungan atau kemudahan akses RTSM untuk mengakses pelayanan kesehatan diluar program PKH seperti Jaminan Kesehatan Masyarakat (Jamkesmas) atau Bantuan Sosial Jaminan Kesehatan (BPJS) sehingga $\mathrm{PKH}$ tidak berdiri sendiri memberi pelayanan kesehatan ke RTSM tapi tetap ada dukungan atau penguatan dari program perlindungan sosial lainya. Karena jaminan kesehatan untuk RTSM perlu diberikan untuk penanggulangan kemiskinan, seperti yag diungkapkan Suharto (2009: 59$)^{7}$ jaminan kesehatan merupakan sistem yang berdiri sejak lama dan sangat diperlukan oleh masyarakat, dimana jaminan kesehatan merupakan pendorong pembangunan dan strategi penting dalam penanggulangan kemiskinan.

b) Intervensi pendidikan

Partisipasi perempuan atau ibu penerima PKH wajib mengontrol partisipasi anak dalam bidang pendidikan yang tidak bergantung hanya pada seberapa banyak waktu yang dihabiskan anak-anak untuk hadir di sekolah, tetapi juga seberapa banyak waktu yang dihabiskan untuk mengerjakan pekerjaan rumah, seberapa berkonsentrasi dan cukup beristirahat mereka untuk dapat mengerjakan pekerjaan sekolah maupun pekerjaan rumah. Seorang anak yang tertidur selama pelajaran dan tidak memiliki waktu atau mengalami kelelahan untuk memberikan perhatian pada pekerjaan sekolah dan rumah, yang disebabkan karena pekerjaan anak yang tidak kasat mata, yakni anak bekerja atas kehendak orangtua di wilayah privat, seperti misalnya membantu pekerjaan orangtua di rumah, bekerja di sistem pertanian keluarga, atau bekerja untuk pekerjaan keluarga akan menghasilkan prestasi yang buruk.

Disisi lain, kita ketahui tentang rendanhnya tingkat pendidikan seorang kepala keluarga menyebabkan penghasilan yang diperoleh juga rendah sehingga tidak mampu memenuhi kebutuhan kesehatan dan pendidikan anak-anaknya. Sementara jka kesehatan ibu hamil pada keluarga miskin tidak memadai pula maka berakibat pada pertumbuhan anaknya. Sehingga pertumbuhan anak keluarga miskin tidak memadai dan berdampak pada rendahnya kapasitas belajar anak. Untuk itu intervensi dalam hal pendidikan ini sangat penting keberadaanya untuk inventasi sumber daya manusia kedepanya, meski nominal bantuanya bisa dikatakan kecil. Pemberdayaan Perempuan (Kesetaraan Gender). 


\section{2) Pemberdayaan Perempuan}

Konsep pemberdayaan perempuan pada dasarnya merupakan paradigma baru pembangunan yang lebih mengaksentuasikan sifat-sifat people centered, participatori emproving sustainable" walaupun pengertianya berbeda namun mempunyai tujuan yang sama yaitu untuk membangun daya, dengan mendorong, memotivasi dan membangkitkan kesadaran akan potensi yang dimilikinya, serta adanya upaya mengembangkan kearah yang lebih baik. Pemberdayaan masyarakat bukanlah sekedar untuk memenuhi kebutuhan dasar atau menyediakan mekanisme pencegahan proses pemikiran lebih lanjut.

Untuk mengetahui kesetaraan gender dalam penelitian ini adalah dengan menggunakan pendekatan analisis Longwe. Pendekatan analisis Longwe atau biasa disebut dengan Kriteria Pembangunan Perempuan (Womens Empowerment Criteria atau Womens Development Criteria) adalah suatu pendekatan analisis yang dikembangkan sebagai metode partisipasi dan pemberdayaan perempuan. Lima dimensi pemberdayaan ini adalah kategori analitis yang bersifat dinamis, satu sama lain berhubungan secara sinergis, saling menguatkan dan melengkapi, serta mempunyai hubungan hierarkhis. Disamping itu kelima dimensi tersebut juga merupakan tingkatan yang bergerak memutar seperti spiral, makin tinggi tingkat kesetaraan otomatis makin tinggi tingkat keberdayaan (Handayani, 2002: 180) ${ }^{8}$.

\section{a) Kesejahteraan}

Dimensi ini merupakan tingkat kesejahteraan material yang diukur dari tercukupinya kebutuhan dasar seperti makanan, penghasilan, perumahan, dan kesehatan yang harus dinikmati oleh perempuan dan laki-laki. Dengan demikian kesenjangan gender ditingkat kesejahteraan ini diukur melalui perbedaan tingkat kesejahteraan perempuan dan laki-laki sebagai kelompok untuk masing-masing kebutuhan dasarnya. Tingkat ini adalah tingkat nihil dari perempuan (zero level of women's empowerment), padahal upaya perempuan untuk memperbaiki kesejahteraannya memerlukan keterlibatan perempuan dalam proses pemampuan dan pada tingkat pemerataan atau persamaan yang lebih tinggi. Dengan kata lain, jika tingkat kesejahteraan yang rendah dari perempuan disebabkan oleh diskriminasi gender yang sistematik maka mengatasi diskriminasi itu mengharuskan adanya proses pemampuan (empowerment) menuju tingkat pemerataan yang lebih tinggi.

Dari hasil penelitian ditemukan bahwa dengan adanya bantuan PKH membantu daya beli mereka untuk keperluan sehari-hari. Karena mereka dari komponen balita selain wajib membawa ke posyandu untuk kesehatan balita mereka, mereka juga harus memberi makanan bergizi untuk balita mereka. Tidak ada permasalahan mereka jika uang bantuan mereka digunakan untuk modal usaha, asalkan kebutuhan dasar untuk balitanya tercukupi. Dan bantuan PKH tersebut tidak menjadikan kesenjangan untuk laki-laki karena pada dasarnya mereka tidak bisa mencukupi kebutuhan dasar yaitu pendidikan untuk anaknya. Hal lain adalah bahwa bantuan PKH memang memungkinkan perempuan dari RTSM penerima PKH memiliki kekuatan membeli yang lebih besar. Dalam bidang kesehatan maupun pendidikan, uang dapat dibelanjakan untuk membeli makanan yang kualitasnya lebih baik daripada sebelumnya, serta obat-obatan yang diperlukan.

Kesejahteraan untuk RTSM penerima PKH adalah tujuan utama dari PKH, sebagaimana yang ada dalam buku pedoman PKH (kementrian Sosial, 2009:2) bahwa dengan PKH diharapkan RTSM penerima PKH (semua anggota keluarganya) mampu memiliki akses yang lebih baik untuk memanfaatkan pelayanan sosial dasar kesehatan, pendidikan, pangan dan gizi termasuk menghilangkan kesenjangan sosial, ketidakberdayaan dan keterasingan sosial yang selama ini melekat pada diri warga miskin.

\section{b) Akses}

Kesenjangan disini terlihat dari adanya perbedaan akses antara laki-laki dan perempuan terhadap sumber daya. Lebih rendahnya akses mereka terhadap sumber daya menyebabkan produktivitas perempuan cenderung lebih rendah dari laki-laki. Selain itu dalam banyak komunitas, perempuan diberi tanggung jawab melaksanakan hampir semua pekerjaan domestik sehingga tidak mempunyai waktu untuk mengurusi dan meningkatkan kemampuan dirinya. Pembangunan perempuan tidak cukup hanya pada pemerataan akses karena kurangnya akses perempuan bukan saja merupakan isu gender tetapi juga isu diskriminasi gender.

Berdasarkan hasil wawancara serta pengamatan di lapangan responden mengatakan bahwa mereka telah mendapatkan akses yang sama dalam memperoleh kesempatan untuk memanfaatkan sumber daya yang ada (baik sumber daya alam, sosial dan politik). Sebelum 
ada PKH perempuan yag ada di Kecamatan Sumberbaru Kabupaten Jember tidak ada kesenjangan gender pada tingkat pemerataan atau persamaan kesejahteraan muncul dari ketimpangan dalam akses terhadap sumbersumber, termasuk kerjanya sendiri (seringkali perempuan memikul kerja yang begitu berat sehingga ia tidak mempunyai waktu untuk mengurus dan meningkatkan kemampuan dirinya). Sedangkan dengan bantuan PKH yang diterima perempuan merasa kedudukanya sama dan memiliki akses yang sama dengan laki-laki dalam mengeluarkan aspirasinya dalam politik. Perempuan tersebut mempunyai keyakinan dengan peran sertanya dalam mengeluarkan suaranya dalam politik taraf hidupnya akan terbantu karena sudah diberi bantuan PKH. Siapapun dalam politik yang menjadi pemimpin mereka berkeyakinan bisa merubah taraf hidupnya.

\section{c) Penyadaran}

Tingkat ini menyangkut kesadaran dari pelaku pembangunan akan adanya ketimpangan struktural dan diskriminasi gender. Kesenjangan gender ditingkat ini disebabkan adanya anggapan bahwa posisi sosial ekonomi perempuan yang lebih rendah dari laki-laki dan pembagian kerja gender tradisional adalah bagian dari tatanan abadi. Pemberdayaan ditingkat ini berarti menumbuhkan sikap kritis dan penolakan terhadap cara pandang diatas bahwa subordinasi terhadap perempuan bukanlah pengaturan alamiah, tetapi hasil diskriminatif dari tatanan sosial yang berlaku. Agar tidak terjadi kesenjangan gender, diperlukan adanya kesadaran kritis bagi perempuan. Kesadaran kritis yang dimaksud dalam penelitian ini adalah adanya pemahaman yang dimiliki oleh perempuan bahwa tidak ada perbedaan antara laki-laki dan perempuan dalam ikut melibatkan diri dalam kegiatan PKH. Ketika perempuan sudah mempunyai kesadaran kritis, maka mereka akan berpartisipasi karena kesadaran mereka bahwa pendidikan dan kesehatan itu penting.

Dalam penelitian ini ditemukan bahwa didalam PKH mengedepankan nilai jika manusia adalah segenap subjek dan aktifitas kehidupan. Orang miskin tidak dipandang sebagai objek yang hanya dicirikan oleh kondisi dan karakteristik kemiskinan, melainkan orang yang juga memiliki seperangkat pengetahuan dan keterampilan yang sering digunakan dalm mengatasi permasalah seputar kemiskinannya. Dalam PKH juga ada proses edukasi yang bertujuan untuk merubah pola pikir (mind set) dan perilaku (behavior) dari peserta PKH yang dilakukan secara terus menerus dalam PKH agar peserta PKH memiliki kesadaran tentang pendidikan dan kesehatan (Kementrian Sosial, 2009:84) ${ }^{9}$. Proses penyadaran dalam lingkup PKH adalah bagaimana para RTSM penerima PKH memiliki mindset atau pola pikir bahwa kesehatan dan pendidikan adalah hal penting untuk memutus rantai kemiskinan yang membelenggu mereka.

\section{d) Partisipasi}

Pada tingkat ini kita berbicara mengenai pemerataan atau persamaan partisipasi perempuan dalam pengambilan keputusan pada semua tahapan perumusan, perencanaan, pelaksanaan, monitoring atau evaluasi. Kesenjangan perempuan dalam partisipasi aktif ini mudah diidentifikasi, misalnya dalam bidang legislatif, eksekutif, organisasi politik. Partisipasi secara umum dapat dilihat dari adanya peran serta setara antara laki-laki dan perempuan dalam pengambilan keputusan, baik di tingkat keluarga, komunitas, masyarakat, maupun negara.

Tetapi dalam PKH sebagai salah satu kebijakan sosial yang bersifat top down tidak melibatkan peserta $\mathrm{PKH}$ dalam pengambilan semua keputusan pada sistem PKH mulai dari perencanaan, pelaksanaan, monitoring atau evaluasi karena yang menentukan adalah pembuat kebijakan. Perempuan disini hanya diminta partisipasi dalam pelaksanaan program untuk mematuhi semua kewajiban dalam PKH saja. Meningkatnya peran serta perempuan merupakan hasil dari pemberdayaan sekaligus sumbangan penting bagi pemberdayaan yang lebih luas. Semua aktivitas menikmati hakhaknya sebagai manusia agar mampu berperan dan berpartisipasi dalam pembangunan, politik, ekonomi, sosial budaya, pendidikan dan hankamnas dan kesamaan dalam menikmati hasil pembangunan tersebut" (Kementrian Pemberdayaan Perempuan, 2001: 9) ${ }^{10}$.

Selain itu perilaku dasar perempuan masih bersifat pasif dalam mengemukakan pendapat untuk berpartisipasi mengemukakan ide-ide atau aspirasi mereka dalam proses pembuatan kebijakan. Budaya patriarkhi masih melekat dan butuh waktu untuk mengikisnya, Arif (2012: 12) mengungkapkan bahwa meski PKH sukses meningkatkan kehadiran siswa di sekolah dan meningkatkan kesehatan anak balita serta ibu yang melahirkan, tetapi PKH belum mampu mengubah relasi gender didalam rumah tangga, akses terhadap uang tunai yang didapatkan perempuan peserta PKH tidak meningkatkan 
posisi tawar permpuan dalam mengambil keputusan penting yang menyangkut penggunaan uang dalam jumlah yang besar di dalam keluarga.

Dalam kerangka pemberdayaan politik, melalui mekanisme yang mewajibkan adanya usulan kegiatan dari anggota yang semua perempuan, dalam PKH mendorong perempuan anggota PKH dapat terlibat dalam proses pengambilan keputusan ditingkat komunitas. Beberapa perempuan diharuskan menduduki posisi strategis didalam struktur pelaksanaan $\mathrm{PKH}$ diberbagai tingkatan sehingga diharapkan mampu mendorong perempuan untuk terlibat politik lokal yg ada dimasyarakat.

\section{e) Kontrol}

Kesenjangan gender ditingkat ini terlihat dari adanya hubungan kuasa yang timpang antara laki-laki dan perempuan, hal ini bisa terjadi ditingkat rumah tangga. Meningkatnya partisipasi perempuan pada tingkat pengambilan keputusan menyebabkan meningkatnya pemampuan untuk mempunyai kontrol (penguasaan) yang lebih banyak terhadap faktorfaktor produksi, dan untuk menjamin persamaan akses terhadap pembagian sumber dan manfaat.

Dari hasil penelitian bisa dikatakan bahwa PKH tidak mampu membuat perempuan RTSM terlibat lebih jauh dalam tingkat pengambilan keputusan yang menyebabkan meningkatnya pemampuan untuk mempunyai kontrol (penguasaan) yang lebih banyak terhadap faktorfaktor produksi, dan untuk menjamin persamaan akses terhadap pembagian sumber dan manfaat. Pada tingkat ini kita berbicara mengenai pemerataan persamaan partisipasi perempuan dalam pengambilan keputusan pada semua tahapan proyek: perumusan, perencanaan, pelaksanaan, monitoring atau evaluasi. Keadaan ini bisa terjadi karena desain PKH sama sekali tidak dibuat untuk mentrasformasikan pola relasi gender didalam rumah tangga dan didalam masyarakat sehingga tidak berdampak pada posisi perempuan dan kesetaraan gender (Holmes, 2010: 8) ${ }^{11}$.

Dalam proses pemberdayaan perempuan, kemandirian perempuan tidak hanya di identifikasi dengan meningkatkan pendapatan saja, tetapi seberapa jauh perempuan tersebut menguasai sumber-sumber ekonomi baru. Sehingga pendapatan dapat meningkat dan berkelanjutan, tetapi kepercayaan hidup selanjutnya didapatkan kemandirian sosial dan ekonomi tersebut wajib dipahami. Disinilah peran pendamping $\mathrm{PKH}$ menyelenggarakan dialog dengan masyarakat untuk menggali kebutuhan-kebutuhan-kebutuhan nyata, menggali sumber potensi yang tersedia, mendorong perempuan RTSM untuk menemukan spesifikasi masalah yang harus dipecahkan dan mengorganisir mereka untuk mengambil tindakan yang tepat.

Kegagalan dalam program-program perlindungan sosial yang untuk menstransformasikan posisi perempuan disebabkan karena kurangnya pemahaman dari pengambilan kebijakan terhadap perspektif gender secara utuh sehingga program-program atau kebijakan perlindungan sosial hanya mampu menjangkau pemberdayaan sebatas peningkatan akses dan partisipasi perempuan, dan tidak pada variabel kontrol maupun variabel manfaat yang didapatkan perempuan. Latar belakang dari perempuan $\mathrm{PKH}$ yang berpendidikan rendah tidak memiliki motivasi ataupun kemauan dalam hal kesetaraan dengan laki-laki dalam kuasa yang berarti adanya kuasa yang seimbang antara lakilaki dan perempuan, satu tidak mendominasi atau berada dalam posisi dominan atas lainnya, artinya perempuan mempunyai kekuasaan sebagaimana juga laki-laki untuk mengubah kondisi, posisi, masa depan diri dan komunitasnya.

Semua upaya kearah kesetaraan gender berupa perlindungan sosial yang transformatif, seharusnya mempertimbangkan pihak laki-laki dan permpuan (suami dan istri) pada kasus tertentu, kesetaraan gender perlu dipahami sebagai upaya untuk memberdayaan perempuan. Namun pada kasus dan sektor tertentu pemberdayaan juga perlu dilakukan pada lakilaki. Perlu dipahami juga bahwa upaya pemberdayaan perempuan perlu dilakukan dengan melibatkan laki-laki karena dinamika hubungan kekuasaan gendr berdampak pada perempuan maupun laki-laki. Oleh karena itu, diperlukan lebih banyak studi untuk melihat secara lebih komperehensif pada kasus dan sektor apa saja perempuan tertinggal dari lakilaki dan begitu pula sebaliknya, serta dinamika pola relasi kekuasaan diranah privat (rumah tangga) dan ranah publik.

\section{3) Faktor-faktor yang menjadi pendukung dan yang menghambat dalam PKH}

(a) Faktor Pendukung

PKH merupakan program yang transparan dan akuntabel dalam perencanaan, pelaksanaan, dan pengawasannya seperti adanya persyaratan bagi calon penerima $\mathrm{PKH}$, verifikasi 
untuk memperoleh $\mathrm{PKH}$, adanya pendampingan untuk penerima $\mathrm{PKH}$, mekanisme pencairan dana PKH dan monitoring secara berkala terhadap penerima PKH.

Yang selanjutnya adalah adanya tenaga pendamping yang merupakan aktor penting dalam suksesnya implementasi kebijakan sosial PKH mulai dari ditingkat kecamatan. Tenaga pendamping menjadi kekuatan tersendiri dalam PKH karena tenaga pendamping dibutuhkan sebagian besar orang miskin yang tidak memiliki kekuatan, tidak memiliki suara dan kemampuan untuk memperjuangkan hak mereka yang sesungguhnya sehingga mereka membutuhkan tenaga pendamping yang mampu menyuarakan hak mereka. Selain itu di tingkat UPPKH Kabupaten tidak memiliki kemampuan melaksanakan tugasnya diseluruh tingkat kecamatan dalam waktu bersamaan. Jadi pendamping sangat dibutuhkan dalam $\mathrm{PKH}$ sebagai pancaindra. Tenaga pendamping harus menghabiskan waktunya dengan melakukan kegiatan dilapangan, yaitu mengadakan pertemuan dengan ketua kelompok, berkunjung dan berdiskusi dengan petugas pemberi pelayanan kesehatan, pendidikan, pemuka daerah maupun dengan peserta penerima PKH. PKH merupakan program yang layak dipertahankan dan ditingkatkan karena transparan dan akuntabel dalam perencanaan, pelaksanaan, dan pengawasannya seperti adanya persyaratan bagi calon penerima $\mathrm{PKH}$,verifikasi untuk memperoleh $\mathrm{PKH}$, adanya pendampingan untuk penerima $\mathrm{PKH}$, mekanisme pencairan dana PKH dan monitoring secara berkala terhadap penerima PKH. Peningkatan kualitas SDM bagi pendamping perlu ditingkatkan agar penerima PKH memahami bahwa dana yang diterima dapat digunakan untuk belanja kebutuhan dasar seperti makanan dan transportasi. PKH yang merupakan proses pemberdayaan untuk perempuan dari RTSM harus tetap dilaksanakan (sustainability development) dengan catatan perlu adanya perubahan yang cukup mendasar pada sistem politik yang menjamin partisipasi efektif, sistem ekonomi yang mampu menghasilkan surplus, sistem sosial yang mampu mengatasi semua hambatan dan tantangan, sistem produksi yang menghargai kewajiban untuk mempertahankan suatu basis ekologis pembangunan, sistem administrasi yang selalu dinamis, mampu menyesuaikan diri dengan fungsi yang terus berubah, dan sistem internasional yang mendorong tumbuhnya pola perdagangan dan keuangan yang berkelanjutan (Soenyono, 2012: 78).

(b) Faktor Penghambat

Beberapa faktor yang menjadi penghambat pelaksanaan PKH di Kecamatan Sumberbaru Kabupaten Jember seperti yang diungkapkan oleh salah satu anggota UPPKH Kecamatan Sumberbaru Kabupaten Jember Selain itu yang menjadi kelemahan dari PKH adalah PKH yang merupakan kebijakan top down sudah tidak sesuai dengan situasi dan kondisi jaman sekarang yang memposisikan semua pembangunan "dari rakyat oleh rakyat dan untuk rakyat". PKH sebagai kebijakan top down dimana kebijakan awal berasal dari pemerintah tidak bisa memenuhi apa yang sebenarnya dibutuhkan oleh perempuan penerima $\mathrm{PKH}$, selain itu semua tidak dilibatkanya peran perempuan RTSM dalam proses awal perencanaan sampai dengan evaluasi akan menyebakan lemahnya partisipasi perempuan penerima $\mathrm{PKH}$ karena tidak ada rasa memiliki dari proses implementasi PKH. Keberadaan PKH sebagai kebijakan yang bersifat top down juga memiliki hambatan yang bersifat politis dalam proses implementasinya, dalam artian baik kebijakan maupun tindakan-tindakan yang diperlukan untuk melaksanakanya tidak diterima atau tidak disepakati oleh stakeholdernya. Sebagai contoh masyarakat yang bukan penerima PKH cenderung menghambat proses implementasi PKH karena adanya faktor kecemburuan sosial mereka tidak mendapat bantuan juga. Kebijakan yang bersifat top down tersebut harus dirubah menjadi kebijakan yang bersifat Bottom Up yang melibatkan partisipasi peserta PKH dari awal perencanaan program sampai dengan kegiatan evaluasi sehingga akan meningkatkan partisipasi dalam implementasi kebijakan. Dalam (Pranaka dan Prijono, 1996: 4)13 dikenal dengan fase partisipatoris dimana suatu proses pemberdayaan berasal dari pemerintah bersama masyarakat, oleh pemerintah dan masyarakat, dan diperuntukkan bagi rakyat. 
4) Rancangan model penanggulangan kemiskinan dalam perspektif pemberdayaan perempuan yang dihasilkan dari implementasi kebijakan PKH

Rancangan model dalam penelitian ini tidak hanya menggambarkan situasi sebuah sistem tanpa rekomendasi dan peramalan, serta tidak hanya menirukan sistem kebijakan aslinya dengan hanya mengambil beberapa karakteristik utama yang menggambarkan sistem lain secara analog. Rancangan model yang ingin diperoleh adalah rancangan model probabilistik dari input atau proses yang menghasilkan yang akan terjadi pada output yang akan dihasilkan. Berikut rancangan model penanggulangan kemiskinan dalam perspektif pemberdayaan perempuan yang dihasilkan dari implementasi kebijakan PKH adalah sebagai berikut:

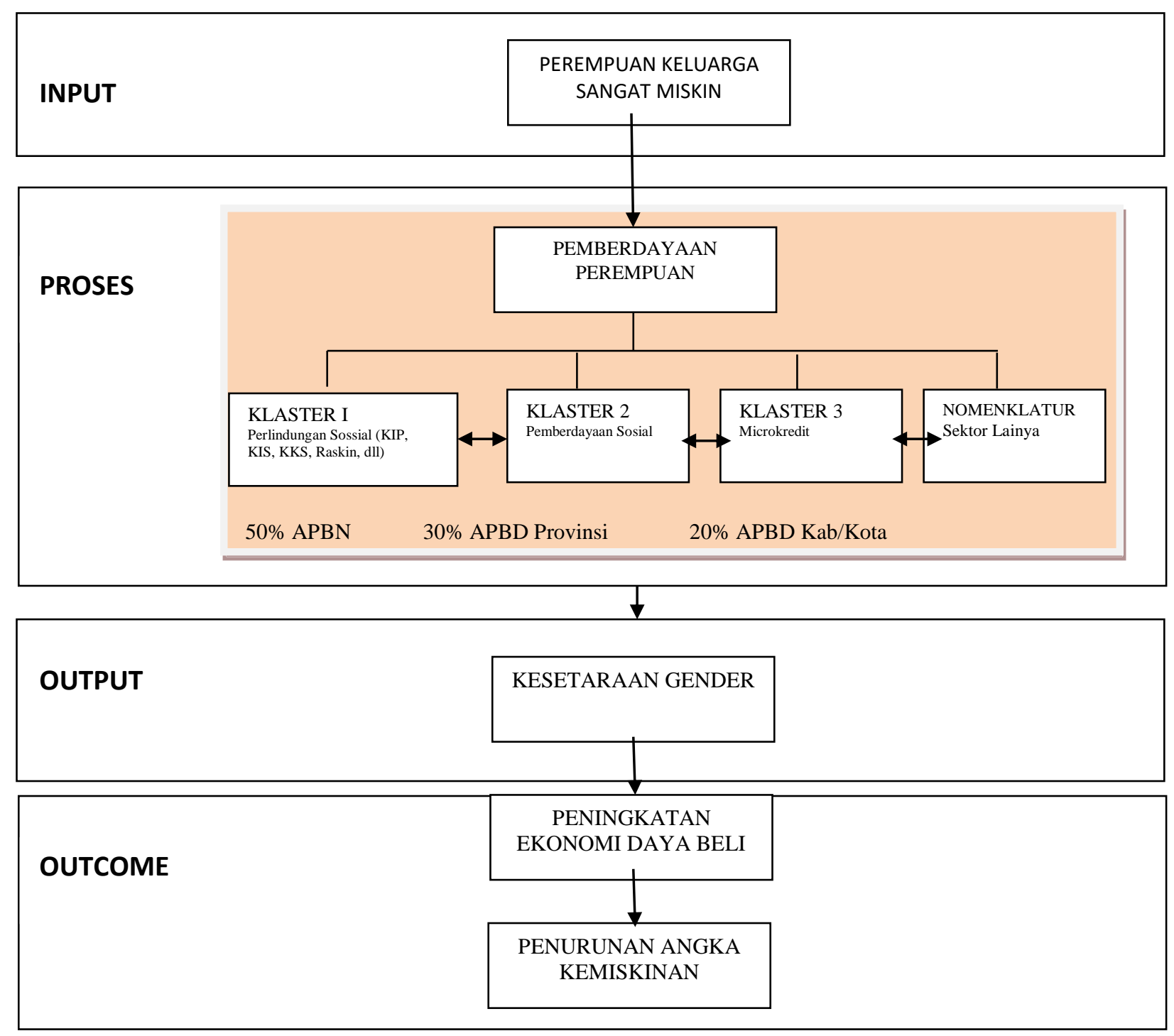

Gambar rancangan model kebijakan penanggulangan kemiskinan dengan perspekif pemberdayaan perempuan 
Bahwa PKH sebagai bagian dari klaster 1 (Perlindungan Sosial) dalam skema kebijakan nasional penanggulangan kemiskinan harus selalu dilihat sebagai simultan, saling mempengaruhi dan saling sinergi dengan klaster lainnya, bukan saling tersekat dan berdiri sendiri-sendiri sebagai sebuah tahapan sekuensial yang kaku terkotakkotak.

Perempuan yang diposisikan subjek penelitian harus diberikan proses pemberdayaan untuk perempuan yang disesuaikan dengan strategi umum pembangunan Jawa Timur yang tertuang dalam Rancangan Pembangunan Jangka Menengah Daerah (RPJMD) dijalankan Dalam proses pemberdayaan perempuan harus ada sinergi antara kebijakan sosial yang dibuat oleh pemerintah baik dari tingkat pusat sampai tingkat daerah, sinergi antara pelaksana kebiijakan sosial dan para stakeholder sehingga kebijakan sosial yang sudah ada bisa terimplementasi dengan baik mengurangi tingkat kemiskinan. Dalam rancangan model ini memakai kebijakan sosial yang berdasarkan pada pembagian Tugas Pokok dan Fungsi (Tupoksi) dan pembagian kelompok program atau yang disebut klaster.

Untuk klaster 1 bantuan sosial terpadu berbasis keluarga, melakukan koordinasi penanggulangan kemiskinan di bidang bantuan sosial terpadu berbasis keluarga. Dengan tujuan melakukan pemenuhan hak dasar, pengurangan beban hidup, dan perbaikan kualitas hidup masyarakat miskin yaitu antara lain Program Keluarga Harapan (PKH), Kartu Keluarga Sejahtera (KKS) Kartu Indonesia Pintar (KIP), Kartu Indonesia Sehat (KIS), program beras miskin (raskin), beasiswa miskin dan Beasiswa Operasional Sekolah (BOS).

$\begin{array}{lrrr}\text { Klaster } & 2 \text { berbasis } & \text { pemberdayaan } \\ \text { masyarakat } & \text { melakukan } & \text { koordinasi } \\ \text { penanggulangan } & \text { kemiskinan } & \text { dibidang }\end{array}$
pemberdayaan masyarakat. Tujuan untuk mengembangkan potensi dan memperkuat kapasitas kelompok masyarakat miskin untuk terlibat dalam pembangunan yang didasarkan pada prinsip-prinsip pemberdayaan masyarakat, kebijakan sosial yang masuk dalam klaster 2 antara lain Program Nasional Pemberdayaan Masyarakat Mandiri (PNPM) dan kebijakan sosial dari pemerintah provinsi Jawa Timur yaitu feminisasi kemiskinan.

Klaster 3 berbasis pemberdayaan usaha ekonomi mikro dan kecil melakukan koordinasi penanggulangan kemiskinan di bidang pemberdayaan usaha ekonomi mikro dan kecil dengan tujuan memberikan akses dan penguatan ekonomi bagi pelaku usaha berskala mikro dan kecil, kebijakan sosial yang masuk dalam kategori klaster 3 adalah Kredit Usaha Rakyat, Koperasi Wanita (Kopwan), dana bergulir BPR melalui Bank Jatim.

Kluster 4 kelompok program lainnya melakukan koordinasi penanggulangan kemiskinan di bidang lainnya dengan tujuan meningkatkan kegiatan ekonomi dan kesejahteraan masyarakat miskin. Kebijakan sosial yang masuk dalam klaster 4 adalah nomenklatur sektor lainya yang meliputi peningkatan investasi, ekspor dan kesempatan kerja; revitalisasi pertanian, perikanan dan kehutanan, dan pembangunan perdesaan; percepatan pembangunan infrastruktur dan peningkatan pengelolaan energi; peningkatan akses dan kualitas pendidikan dan kesehatan; peningkatan efektivitas penanggulangan kemiskinan; pemberantasan korupsi dan percepatan pelaksanaan reformasi birokrasi; penguatan kemampuan pertahanan dan pemantapan keamanan dalam negeri; penanganan bencana, pengurangan risiko bencana, dan peningkatan pemberantasan penyakit menular

Dari empat klaster diatas masing-masing kebijakan sosial harus saling bersinergi dalam memberdayakan perempuan miskin harus saling bersinergi untuk mengimplementasikan kebijakan-kebijakan sosial tersebut sesuai dengan tujuan yang dicapai. Diseleraskan dengan program pemerintah yang tertuang dalam misi RPJMD untuk meningkatkan kesejahteraan rakyat yang berkeadilan untuk mewujudkan kesejahteraan yang berkeadilan bagi semua, melalui peningkatanperluasan lapangan kerja, dan peningkatan pemenuhan serta pemerataan layanan dasar, dengan memperluas akses masyarakat terhadap pendidikan yang bermutu, danperluasan akses terhadap pelayanan kesehatan untuk meningkatkan derajat kesehatan masyarakat, serta percepatan dan perluasan penanggulangan kemiskinan.

Pemberdayaan sebagai implementasi dari pembangunan yang berpusat pada rakyat, tidak saja menumbuhkan dan mengembangkan nilai tambah ekonomis, tetapi juga nilai tambah sosial dan budaya, sehingga partisipasi rakyat akan meningkat menjadi emansipasi rakyat. Output dari rancangan model ini adalah adanya kesetaraan gender untuk perempuan miskin dengan pengarusutamaan gender untuk meningkatkan keadilan dan kesetaraan gender, dimana pada setiap tahapan pembangunan, mulai dari perencanaan, penganggaran, pelaksanaan, 
pemantauan, sampai dengan evaluasi, harus responsif gender. Laki-laki dan perempuan diposisikan sebagai pelaku (subjek) yang setara dalam akses, partisipasi dan kontrol atas pembangunan, serta pemanfaatan hasil pembangunan. Pengarusutamaan gender ditujukan agar semua program pembangunan dilaksanakan dengan membuka kesempatan dan akses perempuan terhadap program pembangunan, agar dapat memberikan manfaat bagi perempuan yang setara dengan laki-laki. Tujuan akhir atau outcome dari pemberdayaan adalah memandirikan masyarakat, dan membangun kemampuan memajukan diri ke arah kehidupan yang lebih baik secara sinambung, dan berdaya saing. Strategi people-centered, participatory, empowering, dan sustainable tersebut lebih luas dari semata-mata memenuhi kebutuhan dasar (basic needs), atau menyediakan mekanisme untuk mencegah proses pemiskinan lebih lanjut (safety net). Konsep ini merupakan strategi pembangunan alternatif, yang menghendaki adanya demokrasi inklusif (inclusive democracy), pertumbuhan ekonomi yang memadai (appropriate economic growth), kesetaraan gender, dan intergenerational equity. Pengembangan demokrasi harus memiliki dampak bagi peningkatan kesejahteraan rakyat, dan memiliki korelasi dengan upaya membebaskan wong cilik dari kemiskinan.

\section{KESIMPULAN}

Dari penelitian berjudul Rancangan Model Kebijakan Penanggulangan Kemiskinan Dalam Perspektif Pemberdayaan Perempuan (Kajian terhadap Implementasi Program Keluarga Harapan di Kecamatan Sumberbaru Kabupaten Jember Tahun 2014) dapat disimpulkan sebagai berikut:

1) Partisipasi perempuan di kecamatan Sumberbaru Kabupaten Jember dalam implementasi belum bisa dikatakan optimal karena PKH sebagai salah satu kebijakan sosial yang bersifat top down tidak melibatkan peserta PKH dalam pengambilan semua keputusan pada sistem PKH mulai dari perencanaan, pelaksanaan, monitoring atau evaluasi karena yang menentukan adalah pembuat kebijakan. Perempuan disini hanya diminta partisipasi dalam pelaksanaan program untuk mematuhi semua kewajiban dalam PKH saja. Kebijakan sosial penanggulangan kemiskinan $\mathrm{PKH}$ ini belum mampu mengubah relasi gender didalam rumah tangga, akses terhadap uang tunai yang didapatkan perempuan peserta $\mathrm{PKH}$ tidak meningkatkan posisi tawar permpuan dalam mengambil keputusan penting yang menyangkut penggunaan uang dalam jumlah yang besar di dalam keluarga.

2) Faktor pendukung dan faktor penghambat implementasi PKH

(a) Faktor pendukung dalam implementasi PKH di Kecamatan Sumberbaru Kabupaten Jember adalah PKH merupakan bantuan uang tunai yang bersyarat untuk perempuan RTSM yang memenuhi komponen PKH sehingga meningkatkan ekonomi daya beli masyarakat tersebut selain itu PKH bersifat transparan dan akuntabel dalam perencanaan, pelaksanaan, dan pengawasannya seperti adanya persyaratan bagi calon penerima $\mathrm{PKH}$, verifikasi untuk memperoleh $\mathrm{PKH}$, adanya pendampingan untuk penerima $\mathrm{PKH}$, mekanisme pencairan dana $\mathrm{PKH}$ dan monitoring secara berkala terhadap penerima. Faktor pendukung lainya adalah adanya tenaga pendamping yang merupakan aktor penting dalam suksesnya implementasi kebijakan sosial PKH mulai dari ditingkat kecamatan. Sehingga PKH merupakan program yang layak dipertahankan dan ditingkatkan.

(b) Faktor penghambat program lebih kepada sikap dan perilaku masyarakat sendiri yang menghambat pelaksanaan program. Selain itu kebijakan PKH yang bersifat Top Down dimana kebijakan awal berasal dari pemerintah tidak bisa memenuhi apa yang sebenarnya dibutuhkan oleh perempuan penerima $\mathrm{PKH}$, selain itu semua tidak dilibatkanya peran perempuan RTSM dalam proses awal perencanaan sampai dengan evaluasi akan menyebakan lemahnya partisipasi perempuan penerima PKH karena tidak ada rasa memiliki dari proses implementasi PKH.

3) Rancangan model kebijakan penanggulangan kemiskinan dengan perspektif pemberdayaan perempuan yang diperoleh dari hasil implementasi PKH di Kecamatan Sumberbaru Kabupaten Jember adalah penyempurnaan dari PKH itu sendiri dengan penajaman program pemberdayaan perempuan terutama perempuan RTSM penerima PKH baik yang masuk kategori PKH maupun non PKH dengan sinergitas dengan klaster lainnya sehingga proses pemberdayaan pada perempuan miskin bisa optimal, selain itu ada penyempurnaan untuk intervensi pendidikan dan kesehatan yang lebih luas sehingga mampu menciptakan adanya kesetaraan 
gender, tujuan jangka panjang yang dicapai adalah meningkatkan ekonomi daya beli perempuan dari keluarga miskin penerima PKH dan menurunkan angka kemiskinan dari perempuan keluarga miskin tersebut.

Sebagai penutup dalam penelitian tentang kebijakan penanggulangan kemiskinan dalam perspektif pemberdayaan perempuan, maka ada beberapa hal berdasarkan hasil dan pembahasan, serta kesimpulan, disampaikan saran-saran sebagai berikut untuk pembuat kebijakan harus mampu mebuat kebijakan sosial penanggulangan kemiskinan PKH ini harus mampu mengubah relasi gender didalam rumah tangga, akses terhadap uang tunai yang didapatkan perempuan peserta PKH tidak meningkatkan posisi tawar permpuan dalam mengambil keputusan penting yang menyangkut penggunaan uang dalam jumlah yang besar di dalam keluarga. Selain itu juga harus ada keterlibatan perempuan dan laki-laki secara setara dalam identifikasi masalah, perencanaan, pengelolaan, implementasi dan monitoring evaluasi, sehingga peran serta perempuan merupakan hasil dari pemberdayaan sekaligus sumbangan penting bagi pemberdayaan yang lebih besar, selain itu perlu adanya sosialisasi untuk semua pihak atau stakeholder untuk pemahaman tentang konsep kesetaraan gender secara menyeluruh baik bagi pendamping, perempuan penrima bantuan maupun kepada masyarakat wilayah sasaran. Selain itu model kebijakan PKH harus dirubah dari model kebijakan top down menjadi bottom up dengan melibatkan partisipasi perempuan penerima $\mathrm{PKH}$ dari proses perencanaan, pelaksaan, monitoring, evaluasi sampai dengan pemanfaatn hasil

\section{UCAPAN TERIMA KASIH}

Terima kasih penulis sampaikan kepada Pemerintah Provinsi Jawa Timur, Gubernur Jawa Timur, dan Universitas Brawijaya yang telah memberikan kesempatan kepada penulis untuk melanjutkan pendidikan program magister sosiologi kajian kemiskinan di Universtas Brawijaya. Terima kasih juga kepada keluarga dirumah yang senantiasa memberikan support dan doa untuk kelancaran penulis dalam menyelesaikan studinya, kepada segenap UPPKH Kabupaten Jember, UPPKH dan terutama tenaga pendamping Kecamatan Sumberbaru Kabupaten Jember atas kesediannya menjadi tempat penelitian bagi penulis.

\section{DAFTAR PUSTAKA}

[1]. Kempson, E. 1996. Life on a low income. York: Joseph Rowntree Foundation. (terjemahan format pdf)

[2]. Pakpahan, Y. M., Suryadarma, D., \& Suryahadi, A. 2009. Destined for destitution: Intergenerational poverty persistence in Indonesia. Jakarta: SMERU Research Institute (SMERU Working Paper, January 2009). Diakses pada 31 Mei 2013, dari http://www.smeru.or.id/report/workpaper/i ntergenpoverty/intergenpoverty.pdf

[3]. Badan Pusat Statistik. 2013. Kecamatan Sumber Baru Dalam Angka 2012. Jember: BPS Kabupaten Jember

[4]. Badan Pusat Statistik. 2014. Kabupaten Jember Dalam Angka 2013. Jember: BPS Kabupaten Jember (PDF Version)

[5]. Arif, Sirojudin dkk. 2012. Risiko Kemiskinan dan Kerentanan Berdimensi Gender: Studi Kasus Program Raskin di Indonesia. Jakarta: The Semeru Research

[6]. Soenyono. 2007. Memahami Penelitian Kualitatif. Jenggala Pustaka Utama. Kediri

[7]. Suharto, Edi. 2009. Kemiskinan dan Perlindungan Sosial di Indonesia "Menggagas Model Jaminan Sosial Universal Bidang Kesehatan". Bandung: Alfabeta

[8]. Handayani, Trisakti dan Sugiarti. 2002. Konsep dan Tekhnik Penelitian Gender. Malang: UMM Press

[9]. Kementrian Sosial,. 2009. Pedoman Umum PKH. Pemerintah Republik Indonesia, Jakarta, Indonesia, 2008

[10]. Kementerian Pemberdayaan Perempuan. 2001. Laki-laki dan Perempuan Memang Beda, Tetapi Tidak Untuk Dibeda-bedakan. Jakarta: Kantor Meneg PP

[11]. Holmes, dkk. 2010. Peran Perlindungan Sosial dan Mengatasi Masalah Ketahanan Pangan dan Gizi Rendah di Indonesia: Sebuah Pendekatan Gender. Jakarta: The Smeru Research

[12]. Soenyono. 2012. Sosiologi Pemberdayaan Masyarakat. Jenggala Pustaka Utama. Surabaya.

[13]. Pranarka Prijono, Onny S. dan AMW., (ed.), 1996, Pemberdayaan: Konsep, Kebijakan dan Implementasi, Jakarta: CSIS 